\title{
Injury Prevention
}

\section{Multifactorial falls prevention programmes for older adults presenting to the Emergency Department with a fall: systematic review and meta-analysis}

\begin{tabular}{|c|c|}
\hline Journal: & Injury Prevention \\
\hline Manuscript ID & injuryprev-2019-043214 \\
\hline Article Type: & Systematic review \\
\hline $\begin{array}{r}\text { Date Submitted by the } \\
\text { Author: }\end{array}$ & 28-Feb-2019 \\
\hline Complete List of Authors: & $\begin{array}{l}\text { Morello, Renata; Monash University, Department of Epidemiology and } \\
\text { Preventive Medicine } \\
\text { Soh, Sze-Ee; Monash University, Deparment of Epidemiology and } \\
\text { Preventive Medicine } \\
\text { Ayton, Darshini; Monash University, Department of Epidemiology and } \\
\text { Preventive Medicine } \\
\text { Behm, Kate; Monash University, Department of Epidemiology and } \\
\text { Preventive Medicine } \\
\text { Egan, Amy; Monash University, Department of Epidemiology and } \\
\text { Preventive Medicine } \\
\text { Hill, Keith; Curtin University, School of Physiotherapy and Exercise } \\
\text { Science } \\
\text { Flicker, Leon; University of Western Australia, Centre for Medical } \\
\text { Research } \\
\text { Arendts, Glenn; University of Western Australia, Perth, Western Australia } \\
\text { and Harry Perkins Institute for Medical Research, } \\
\text { Waldron, Nicholas } \\
\text { Redfern, Julie; University of Sydney, Westmead Applied Research } \\
\text { Centre, Faculty of Medicine and Health } \\
\text { Haines, Terrence; Monash University, Department of Physiotherapy } \\
\text { Lowthian, Judy; Bolton Clarke Research Institute } \\
\text { Nyman, Samuel } \\
\text { Cameron, Peter; National Trauma Research Institute, Alfred Hospital; } \\
\text { Monash University, Epidemiology and Preventive Medicine } \\
\text { Fairhall, Nicola; University of Sydney, Institute for Musculoskeletal } \\
\text { Health, Sydney School of Public Health } \\
\text { Barker, Anna; Monash University, Department of Epidemiology and } \\
\text { Preventive Medicine }\end{array}$ \\
\hline Keywords: & $\begin{array}{l}\text { Fall < Mechanism, Systematic Review < Methodology, Hip Facture < } \\
\text { Injury Diagnosis, Prehospital < Populations/Contexts }\end{array}$ \\
\hline
\end{tabular}




\section{SCHOLARONE ${ }^{\text {M }}$ Manuscripts}


1 Multifactorial falls prevention programmes for older adults presenting to the Emergency

2 Department with a fall: systematic review and meta-analysis

3

4 Authors

5 Morello RM ${ }^{1}$, Soh S-E ${ }^{1,2}$, Behm K${ }^{1}$, Egan A ${ }^{1}$, Ayton DR ${ }^{1}$, Hill $\mathrm{KD}^{3}$, Flicker L ${ }^{4,5}$, Etherton-Beer

$6 \mathrm{CD}^{4,5}$, Arendts $\mathrm{G}^{6}$, Waldron $\mathrm{N}^{7}$, Redfern $\mathrm{J}^{8}$, Haines T ${ }^{9}$, Lowthian JA ${ }^{1,10}$, Nyman S R ${ }^{11}$, Cameron

$7 \quad \mathrm{P}^{1,12}$, Fairhall $\mathrm{N}^{13}$, Barker AL ${ }^{1}$

8

9 Author Affiliations

$10{ }^{1}$ Department of Epidemiology and Preventive Medicine, Monash University, Melbourne,

11 Victoria, Australia

$12{ }^{2}$ Department of Physiotherapy, Monash University, Melbourne, Victoria, Australia

$13{ }^{3}$ School of Physiotherapy and Exercise Science, Curtin University, Perth, Western Australia,

14 Australia

$15{ }^{4}$ WA Centre for Health \& Ageing, Medical School, University of Western Australia, Perth,

16 Western Australia, Australia

17 Department of Geriatric Medicine, Royal Perth Hospital, Perth, Western Australia, Australia

$18{ }^{6}$ School of Medicine, University of Western Australia, Perth, Western Australia

$19{ }^{7}$ School of Medicine, University of Notre Dame Australia, Fremantle, Western Australia,

20 Australia

$21{ }^{8}$ University of Sydney, Westmead Applied Research Centre, Faculty of Medicine and Health,

22 NSW, Australia

$23{ }^{9}$ Department of Physiotherapy, Monash University, and Allied Health Research Unit, Monash

24 Health, Melbourne, Victoria, Australia

$25{ }^{10}$ Bolton Clarke Research Institute, Bolton Clarke, Melbourne, Victoria, Australia 
$26{ }^{11}$ Department of Psychology and Ageing \& Dementia Research Centre, Bournemouth

27 University, Poole, Dorset, UK

$28 \quad{ }^{12}$ Alfred Health, Melbourne, Victoria, Australia

$29{ }^{13}$ Institute for Musculoskeletal Health, Sydney School of Public Health, Faculty of Medicine and

30 Health, The University of Sydney, Sydney, Australia

32 Correspondence to:

33 Dr Renata Morello

34 Department of Epidemiology and Preventive Medicine

35 Monash University

36 The Alfred Centre

3799 Commercial Road

38 Melbourne, VIC 3004

39 Email: renata.morello@monash.edu

40 Phone: +61399030923

$41 \quad$ Fax: +61399030556 


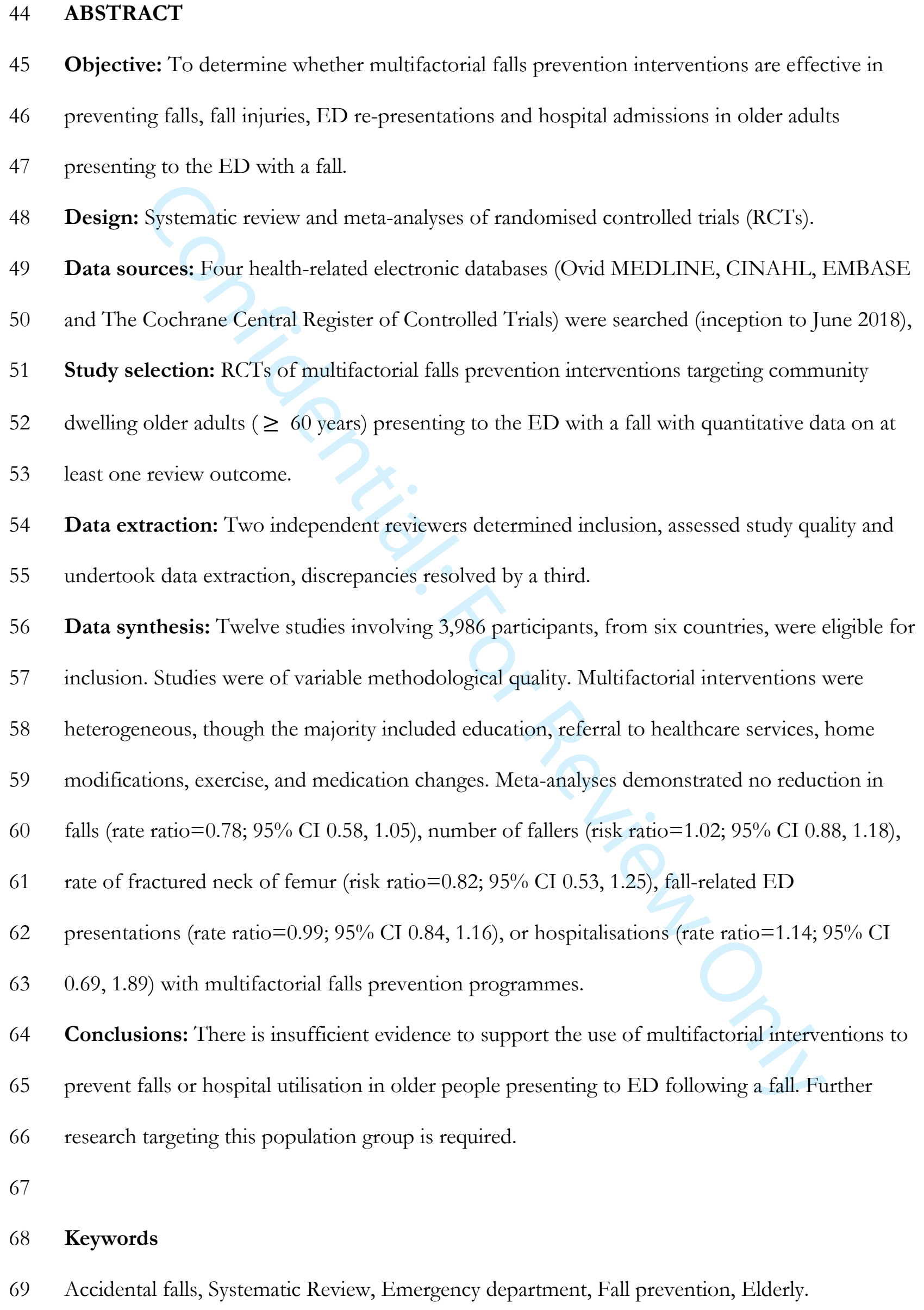




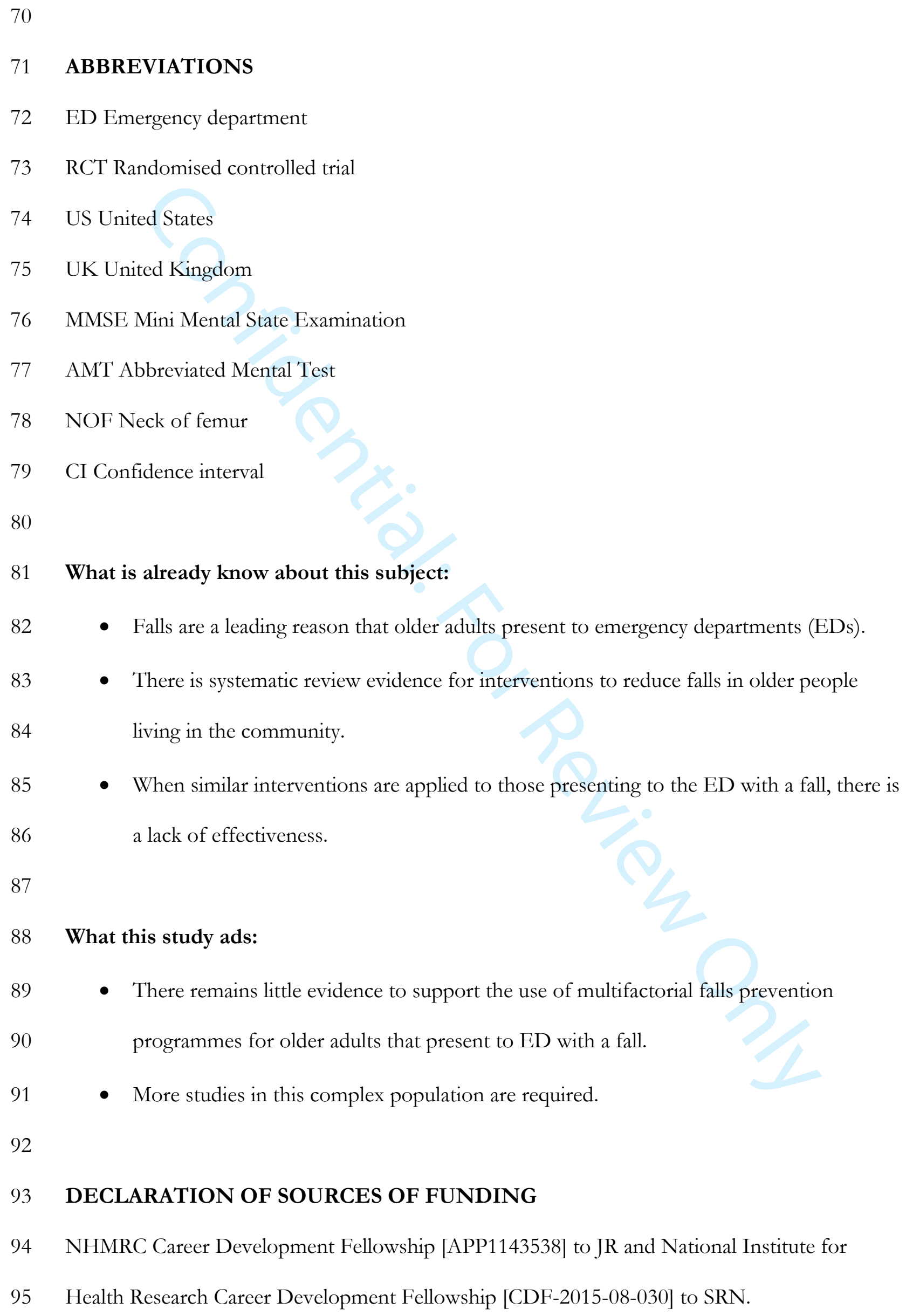

- Falls are a leading reason that older adults present to emergency departments (EDs).

- There is systematic review evidence for interventions to reduce falls in older people living in the community.

- When similar interventions are applied to those presenting to the ED with a fall, there is

What this study ads: a lack of effectiveness.

- There remains little evidence to support the use of multifactorial falls prevention programmes for older adults that present to ED with a fall.

- More studies in this complex population are required.

\section{DECLARATION OF SOURCES OF FUNDING}

94 NHMRC Career Development Fellowship [APP1143538] to JR and National Institute for 95 Health Research Career Development Fellowship [CDF-2015-08-030] to SRN. 
97 ACKNOWLEDGEMENTS

98 We acknowledge Eliza Bradley, Research Assistant, for assistance with final stages of manuscript

99 editing.

100

14

15

16 
102 Falls are a leading cause of emergency department (ED) presentations in older adults ${ }^{1,2}$. In the 103 United States (US), an older adult is treated in the ED for a fall every 15 seconds, and an older 104 adult dies following a fall every 29 minutes $^{3}$. It is estimated that $f_{2} .3$ billion is spent annually on 105 fall-related injuries in people over the age of 65 in the United Kingdom (UK) ${ }^{4}$. Age-standardised 106 rates of hospitalised fall-related injury cases in older Australians are also steadily increasing ${ }^{5}$. Fall-

107 related presentations to the ED are not isolated events; older patients frequently experience 108 subsequent falls $(46 \% \text { to } 56 \%)^{6}$; re-hospitalisation $(49 \%)^{7}$, and substantial functional decline ${ }^{7}$ in 109 the 12 months following ED presentation.

111 Clinical practice guidelines in the US, UK and Australia recommend the use of multifactorial 112 interventions that involve an assessment of individual risk factors, followed by specific interventions targeted to those identified risk factors, to prevent falls in older adults living in the community ${ }^{4,8,9}$. A number of systematic reviews have also established evidence for the effectiveness of multifactorial interventions in reducing falls in community dwelling older transferrable to those recently discharged from hospital ${ }^{13}$. These conflicting results are likely because of the different care needs of the populations concerned ${ }^{14}$. There is a lack of current evidence on the effectiveness of fall prevention interventions for older people presenting to the ED with a fall, who have different care needs to their community-dwelling peers and those who have been recently discharged from hospital ${ }^{15}$. 
127 An updated review of the effects of multifactorial interventions in people presenting to the ED

128 is warranted, given the addition of new published trials, the increasing number of older people at

129 risk $^{16}$, the major physical and psychological consequences associated with falls ${ }^{17,18}$ and high

130 associated healthcare costs ${ }^{19}$. The purpose of this review was to determine the effects of

131 multifactorial falls prevention interventions on falls, fall injuries, fractures, ED presentations and

132 hospitalisations in older adults presenting to the ED with a fall. The results will be of importance

133 to healthcare services and policy makers considering the high cost of the associated injuries and

134 management, and the costs associated with implementing such interventions ${ }^{20}$. 


\section{METHODS}

137 A systematic review and meta-analysis was performed according to the criteria of the Preferred 138 Reporting Items for Systematic Reviews and Meta-analyses. ${ }^{21}$

\section{Search strategy and selection criteria}

141 Four electronic databases (Ovid MEDLINE, CINAHL, EMBASE and The Cochrane Central

142 Register of Controlled Trials (CENTRAL)) were searched, from inception to June 2018. A

143 sensitive search strategy was developed using medical subject heading (MESH) search terms and

144 keywords (Appendix 1 outlines full Medline search strategy), and was customised to each

145 database as needed. References of included studies were reviewed for further relevant literature.

\section{$147 \quad$ Eligibility criteria}

148 Study inclusion criteria: (1) randomised controlled trials (RCT) published in English; (2) included

149 participants aged 60 years or older who presented to an ED after a fall; (3) the intervention primary care or community setting) were excluded from this review. 
162 Initially, two reviewers independently screened and excluded studies based on title and abstracts.

163 For articles not excluded, full-text versions were independently assessed by both reviewers to

164 determine if they met inclusion criteria. In the event of multiple reports from one trial, only the

165 study with the most complete reporting was retained. Disagreements were resolved by a third

166 reviewer if required. Reviewers independently extracted data from included studies.

167 Demographic information (including country of origin, population specifications, sample size),

168 definitions for fall and hospital outcomes and intervention characteristics (such as falls-risk

169 assessments, healthcare professional undertaking the assessment, the intervention strategies used,

170 timing and intensity of interventions offered, and participation) were extracted using a

171 standardised data extraction form. Data available for all relevant outcomes were extracted and 172 tabulated.

173

\section{Methodological quality assessment}

All included studies were assessed for methodological quality by the same reviewers using the PEDro scale ${ }^{23}$. This scale rates 11 aspects of methodological quality of RCTs as being either absent or present. A third reviewer was called upon if consensus could not be reached.

\section{Data synthesis and meta-analysis}

180 Study characteristics and demographic data, such as sample size, gender, and age of participants

181 were reported using mean (SD), median (IQR) or frequency. Meta-analysis was conducted to assess the effect of multifactorial interventions on review outcomes. The rate ratio and $95 \%$ confidence interval (if available) was used to describe the treatment effect for falls, fractures, ED presentations and hospitalisations. For the outcome of faller versus non-faller, we used the risk ratio and $95 \%$ confidence interval as the treatment effect. If both adjusted and unadjusted effect estimates were reported, we used the unadjusted estimate unless the adjustment was for clustering. Effect estimates were manually calculated when needed. When a study reported 
multiple effect estimates for an outcome, the follow up most comparable with other studies, or

189 with the longest follow-up, or adjusted for the largest number of covariates was selected. We

190 conducted two pre-planned subgroup analyses; 1) based on frequency of interventions

191 (interventions with two or more interactions versus those that included less than two), and 2)

192 type of interventions included (interventions including only referral based interventions versus

193 those that included direct treatment to address risk factors).

194

195 As heterogeneity of data was anticipated, due to differences in study populations, follow-up

196 duration and intervention components, a random effects model was used. An inverse variance

197 method was also used to weight each estimate. Between-study variability was assessed using the

$198 \mathrm{I}^{2}$ statistic $^{24}$, where $\mathrm{I}^{2}$ values greater than $50 \%$ were considered to have a high degree of statistical

199 heterogeneity ${ }^{25}$. Where data was unable to be pooled in a meta-analysis due to heterogeneity of

200 outcome measures, descriptive analysis was performed. All analyses were conducted with the use

201 of Review Manager, version 5.2 (RevMan, The Cochrane Collaboration; Oxford, UK).

202 
203 RESULTS

\section{Search yield}

205 The electronic search identified 851 potential studies for screening of eligibility, after duplicate

206 studies were removed. Following screening of titles and abstracts and full-text review, 12 studies

207 were retained for inclusion (Figure 1), based on our described inclusion and exclusion criteria.

208 There were a total of 3,986 participants in the trials included. The median number of participants

209 randomised per trial was 340 (range $109^{26}$ to $712^{6}$ ). Mean age was 78 years and ranged across

210 studies from $73^{27}$ to $84^{28}$ years. Average gender mix was $69 \%$ female (ranging from $55 \%$ to $2118029 \%$ )

212

$213<<$ Insert Figure 1>>

215 Study and sample characteristics

216 The 12 included studies were published between 1999 and 2018 and conducted in six countries

217 (Table 1). Population age was specified as equal or greater than 65 years in all studies except

218 two ${ }^{6,27}$, which included those 60 years and above. Ten studies excluded participants with

219 cognitive impairment, although definitions varied across studies. Five studies utilised the Mini

220 Mental State Examination (MMSE) (score ranging from 16 to $\geq 25$ ), three the Abbreviated

221 Mental Test (AMT) (scores ranging from 4 to $\geq 7$ ) and two did not use a validated tool (patients

222 were excluded based on being described as having dementia in hospital records). Only one study

223 included older people with cognitive impairment $(\mathrm{MMSE}<24)^{29}$.

$<<$ Insert Table 1 $>>$ 


\section{Methodological quality of included studies}

228 Studies were of variable methodological quality (Table 1). Methodological strengths included

229 allocation concealment and between-group comparisons for statistical analysis. Common

230 limitations were the lack of blinding and inadequate follow-up of participants. The complete

231 PEDro assessment of studies have been outlined in Appendix 2 in the supplementary data on

232 the journal website.

\section{Multifactorial falls assessment and interventions}

235 All studies included an assessment of falls risk factors (Appendix 3 provides a detailed summary).

236 Assessment tools and risk factors assessed varied considerably across studies, as did the type of

237 healthcare professionals undertaking the assessments. The most common falls risk factors

238 assessed were home environment (10 studies), mobility or gait (9 studies), vision (10 studies) and

239 balance (7 studies). The time from index fall until baseline assessment was described in five

240 studies, and ranged from within two weeks to one month after the fall-related ED presentation.

241 Assessments were also undertaken in a variety of settings and on occasion by more than one

242 health professional, including the participant's home (10 studies), an outpatient setting e.g. day

243 hospital or clinic (4 studies) or as an inpatient (2 studies).

Table 2 provides a detailed summary of the interventions of included studies. Interventions were

246 led by a variety of healthcare professionals, including occupational therapists, physiotherapists,

247 registered nurses and medical professionals. The specific interventions delivered were highly

248 variable, including education (11 studies), referral to healthcare services (11 studies), home

249 modifications (8 studies), exercise (6 studies) and medication change (5 studies). Some studies

250 provided only limited treatment options, such as education and referral to healthcare services,

251 whilst others provided many potential intervention strategies. The time until delivery of

252 intervention was reported in only six studies, and ranged from two to eight weeks after 
253 completion of baseline assessment. Frequency of the recommended interventions varied from

254 one to up to 16 sessions. Only six of the 12 included studies reported on patient uptake of

255 referrals and/or fall prevention recommendations, ranging from $7 \% \%^{6}$ to $100 \%{ }^{28}$.

256

257

$<<$ Insert Table 2>

258

\section{Outcome measures}

260 A number of fall outcomes were captured across the 12 studies (Table 1). Studies used varying

261 definitions for these outcomes, summarised in Appendix 4. All studies utilised falls calendars or

262 diaries to record information on falls. Of these, 11 studies required participants to return the

263 calendar regularly (weekly, monthly), nine contacted the participants monthly to verify/retrieve

264 falls data from the calendar, whilst one collected data only on follow-up (12 months $)^{30}$. All

265 studies, except one ${ }^{31}$ that included ED presentations and/or hospital admissions as an outcome

266 measure, assessed medical records to confirm details. The length of follow up for studies was

267 between six and 12 months.

268

269 Effectiveness of falls prevention interventions

270 Rate of falls and number of fallers

271 As shown in Figure 2a, there was no reduction in the rate of falls (rate ratio $0.78,95 \%$ CI 0.58 to

272 1.05) with the use of multifactorial falls prevention programmes. Nor did the programmes

273 significantly reduce the number of fallers (risk ratio $1.02,95 \%$ CI 0.88 to 1.18 ; Figure $2 \mathrm{~b}$ ).

274 Substantial statistical heterogeneity was noted between individual studies for both the rate of falls

$275\left(\mathrm{I}^{2}=94 \%\right)$ and the number of fallers $\left(\mathrm{I}^{2}=75 \%\right)$. Subgroup analyses demonstrated that studies that

276 included two or more interactions in their multifactorial intervention programme had a

277 significant reduction in the rate of falls (rate ratio 0.62, 95\% CI 0.45 to 0.86 ) (Appendix 5).

278 Similarly, studies which included treatment of risk factors, rather than just referral based 
279 interventions, demonstrated a significant reduction in the rate of falls (rate ratio $0.78,95 \% \mathrm{CI}$

2800.58 to 0.93$)$. No difference was observed for number of fallers in these subgroups.

Fall injuries and injurious falls

283 Meta-analyses were not performed for fall injuries and injurious falls, as the definitions were too 284 heterogeneous across included studies (Appendix 4). However, of the eight studies that reported 285 on either injurious falls or fall injuries, no study observed a statistically significant effect.

Number of fractures

288 Due to the variability in the type of fractures reported, only studies that reported on the same 289 outcome of a fractured neck of femur (NOF) were included in this meta-analysis (3 studies).

290 Multifactorial falls prevention programmes did not significantly reduce the number of fractured

291 NOFs (risk ratio $0.82,95 \%$ CI 0.53 to 1.25 ; Figure 2 c). Of the remaining two studies that 292 reported on other fractures, one ${ }^{27}$ reported a reduction in the rate of fractures in the intervention 293 group (incidence rate ratio $0.37,95 \%$ CI 0.15 to 0.91 ). The other study ${ }^{6}$ observed no effect on 294 fractures.

Rate of fall-related ED presentations and hospitalisations

297 Due to the limited number of studies that reported all-cause ED presentations and

298 hospitalisations, only fall-related ED presentation or hospitalisation outcomes are reported. The 299 pooled data demonstrates no significant effect on the rate of fall-related ED presentations (rate 300 ratio $0.99,95 \%$ CI 0.84 to 1.16 ; Figure 2 d), or fall-related hospitalisations (rate ratio $1.14,95 \%$ CI

3010.69 to 1.89; Figure 2e). Statistical heterogeneity was noted between individual studies for 302 hospitalisations $\left(\mathrm{I}^{2}=58 \%\right)$. Of the three studies that reported all-cause ED presentations and/or 303 hospitalisations, no study observed a statistically significant effect on either outcome. Subgroup 
304 analyses did not identify any difference in the results for fractures, ED presentations or

305 hospitalisations.

306

$307<<$ Insert Figure 2>>

308

309 DISCUSSION

310 This review extends upon previous reviews on the effect of multifactorial falls prevention

311 programmes ${ }^{10,12}$ focusing on the specific population of older adults who present to ED with a

312 fall. It includes seven additional studies published since the review by Gates and colleagues in

$3132007^{11}$. We found that multifactorial intervention programmes did not reduce falls in older

314 people who present to the ED with a fall, unless the programme included two or more

315 interactions, or the treatment of risk factors, rather than referral-based interventions alone. No

316 significant reductions were observed in the number of fallers, fractured NOFs, ED presentations

317 or hospitalisations with the delivery of multifactorial falls prevention programmes. We were

318 unable to synthesise data relating to rates of injuries, due to the variability in how this outcome

319 was defined.

320

321 There are three key reasons that may have contributed to the limited findings of effect;

322 heterogeneity of multifactorial interventions, poor tailoring of interventions to the ED

323 population, and the inconsistent definition of outcomes between studies. The findings of this

324 review are consistent with findings from the recently updated Cochrane systematic review which

325 examined the efficacy of multifactorial interventions in community-dwelling older adults ${ }^{12}$. As

326 observed by Hopewell et al. (2018), we noted substantial diversity between the multifactorial

327 interventions delivered within studies included in our review. Some studies managed multiple

328 risk factors with multiple intervention strategies from a variety of healthcare professionals over 
numerous interactions, while others concentrated more on education and home modifications in

a single interaction. Studies also used various suites of multifactorial interventions. Although the majority of studies included referral to relevant healthcare services and education, the location and mode of delivery of the interventions were different. Based on results from our subgroup analyses, programmes should at minimum include more than one interaction or actual treatment of one or more risk factor, and not be purely referral based. Meta-analyses of the number of fallers, rate of falls and rate of ED presentations showed significant statistical heterogeneity $\left(\mathrm{I}^{2}\right.$ 58-94\%). Whilst is it expected that multifactorial interventions will differ based on a person's individual risk factors, the low number of studies and the heterogeneity observed may have diluted any possible effects. dwelling older adults. People that present to the ED as a result of a fall, are generally older, frailer, have higher risk of subsequent falls, have more multi-morbidity, complex social issues and more severe injuries when compared to those who do not attend the $\mathrm{ED}^{15,37}$. The ED is a challenging environment in which to initiate falls prevention interventions as staff, workflows and processes are focused on managing the acute care needs of a patient (e.g. injury assessment and management) as opposed to prevention. The studies included in this review may not have

348 sufficiently addressed these differences.

Finally, our outcomes of interest were rate of falls, rate of ED presentations and hospitalisations, number of fallers and number of fractures. Similar to the review by Hopewell and colleagues (2018), it was apparent in our review that these outcomes were defined inconsistently across the included studies. Definitions varied for falls and fall injuries. Some studies excluded specific 
355 rest on furniture or a wall) whereas others included all falls. The rate of peripheral fractures has

356 been recommended as the only robust and feasible measure of an injury ${ }^{12,38}$. However, only

357 NOF fractures were able to be pooled in this review, due to varying definitions. As injuries

358 related to falls contribute to the significant burden on the health of patients, and the healthcare

359 system $^{19}$, it is important that these more robust outcome measures are consistently defined and

360 reported to allow pooling of results in future reviews ${ }^{10,38,39}$. The lack of effect on hospitalisation

361 outcomes may reflect the broader health concerns in this population.

362

363 Adherence to fall prevention recommendations and referrals is an important consideration when

364 assessing the efficacy of a falls prevention programme, particularly when numerous interventions

365 are being provided. However, we found adherence to be inconsistently reported. Previous

366 studies have found that participation and engagement in falls prevention programmes in general

367 community dwelling older adults is likely to be around $50 \%$ at 12 months ${ }^{40}$. A likely contribution

368 to those that present to ED with a fall having poorer participation and engagement in fall

369 prevention programmes may be their complex health needs. Poor adherence could also be

370 explained by the "better for others than for me" phenomenon as described by Haines et al,

371 where individuals at risk of falls can see benefits in falls prevention interventions generally, but

372 do not adhere to these as they do not believe the interventions are relevant to them ${ }^{41}$. When

373 developing new interventions it is important to consider the full range of factors that may

374 influence the effectiveness of an intervention including factors that may limit engagement and

375 participation ${ }^{40}$. Future research would benefit from exploring these factors this population group

376 in more detail.

378 Study limitations

379 This review was undertaken using the robust methods recommended in the PRISMA statement.

380 Limitations include the consideration of papers only published in English, potentially excluding 
381 other high-quality studies, and the analysis of only objective outcomes (eg falls, fall injuries).

382 Subjective information regarding fear of falling, falls self-efficacy and health related quality of life

383 were not considered, which may have provided further insight into meaningful change in

384 psychological consequences of falls, that contribute to the overall burden. The majority of

385 studies also excluded older adults with significant cognitive impairment, which restricts

386 generalisability of this review's findings to those with delirium or dementia. All studies only had a

387 maximum follow-up period of 12 months. It is possible that different conclusions may result if a

388 longer follow-up was applied for these less sensitive measures. Despite the limitations, this

389 review reinforces the fact that falls prevention for this high-risk population is complicated and

390 current guidelines regarding falls prevention practices may need to be targeted specifically for

391 this population.

392

393 Conclusion

394 Falls and their sequelae are a significant health burden worldwide. This systematic review and

395 meta-analysis of randomised controlled trials found little evidence to support the use of

396 multifactorial falls prevention programmes for older adults that present to ED with a fall. More

397 studies in this complex population are required. Studies with a reproducible type and dose of

398 intervention, and powered to detect effects on fall injuries and fractures, are needed to resolve

399 the uncertainty of effectiveness of intervening in this population group. Research with consistent

400 definitions of fall outcomes, along with adequate reporting of intervention components, intensity

401 and adherence are crucial. 


\section{REFERENCES}

403 1. Scuffham P, Chaplin S, Legood R. Incidence and costs of unintentional falls in older 404 people in the United Kingdom. J Epidemiol Community Health 2003; 57(9): 740.

405 2. Owens P, Allison Russo C, Spector W, Mutter R. Emergency Department Visits for 406 Injurious Falls among the Elderly, 2006: Statistical Brief \#80. Rockville (MD): Agency for 407 Healthcare Research and Quality (US): Healthcare Cost and Utilization Project (HCUP) 408 Statistical Briefs [Internet]; 2006.

409 3. Centers for Disease Control and Prevention. Falls among older adults: an overview. 410 2012. http://webappa.cdc.gov/sasweb/ncipc/nfilead2001.html.

411 4. National Institute for Health and Care Excellence. Falls in older people: assessing risk 412 and prevention. 2013. https://www.nice.org.uk/guidance/cg161 (accessed 27 April 2018).

413 5. Bradley C. Hospitalisations due to falls by older people, Australia: 2009-10. Injury 414 research and statistics series no. 70. Cat. no. INJCAT 146. . Canberra: AIHW, 2013.

415 6. Russell MA, Hill KD, Day LM, et al. A randomised controlled trial of a multifactorial 416 falls prevention intervention for older fallers presenting to emergency departments. J Am Geriatr 417 Soc 2010; 58(12): 2265-74.

418 7. Bloch F, Jegou D, Dhainaut JF, et al. Do ED staffs have a role to play in the prevention 419 of repeat falls in elderly patients? Am J Emerg Med 2009; 27(3): 303-7.

420 8. Australian Commission on Safety and Quality in Healthcare. Preventing Falls and Harm 421 from Falls in Older People - Best Practice Guidelines for Australian Community Care 2009.

422 https://www.safetyandquality.gov.au/wp-content/uploads/2012/01/Guidelines-COMM.pdf 423 (accessed 27 April 2018).

424 9. Guideline for the prevention of falls in older persons. American Geriatrics Society, 425 British Geriatrics Society, and American Academy of Orthopaedic Surgeons Panel on Falls 426 Prevention. J Am Geriatr Soc 2001; 49(5): 664-72. 
427 10. Gillespie LD, Robertson MC, Gillespie WJ, et al. Interventions for preventing falls in 428 older people living in the community. Cochrane Database Syst Rev 2012; (9): CD007146.

429 11. Gates S, Fisher JD, Cooke MW, Carter YH, Lamb SE. Multifactorial assessment and 430 targeted intervention for preventing falls and injuries among older people in community and 431 emergency care settings: systematic review and meta-analysis. BMJ 2008; 336(7636): 130-3.

432 12. Hopewell S, Adedire O, Copsey BJ, et al. Multifactorial and multiple component 433 interventions for preventing falls in older people living in the community. Cochrane Database Syst 434 Rev 2018; 7: CD012221.

435 13. Naseri C, Haines TP, Etherton-Beer C, et al. Reducing falls in older adults recently 436 discharged from hospital: a systematic review and meta-analysis. Age Ageing 2018; 47: 521-19.

437 14. Winter H, Watt K, Peel NM. Falls prevention interventions for community-dwelling 438 older persons with cognitive impairment: a systematic review. Int Psychogeriatr 2013; 25(2): 215-27.

439 15. Aminzadeh F, Dalziel WB. Older adults in the emergency department: A systematic 440 review of patterns of use, adverse outcomes, and effectiveness of interventions. Ann Emerg Med $441 \quad 2002 ; 39(3): 238-47$.

442 16. Shankar KN, Liu SW, Ganz DA. Trends and Characteristics of Emergency Department 443 Visits for Fall-Related Injuries in Older Adults, 2003-2010. West J Emerg Med 2017; 18(5): 785-93.

444 17. Yardley L, Smith H. A prospective study of the relationship between feared 445 consequences of falling and avoidance of activity in community-living older people. Gerontologist $446 \quad 2002 ; 42(1): 17-23$.

447 18. Stel VS, Smit JH, Pluijm SM, Lips P. Consequences of falling in older men and women 448 and risk factors for health service use and functional decline. Age Ageing 2004; 33(1): 58-65.

449 19. Stevens JA, Corso PS, Finkelstein EA, Miller TR. The costs of fatal and non-fatal falls 450 among older adults. Inj Prev 2006; 12(5): 290-5. 
451 20. Church J, Goodall S, Norman R, Haas M. The cost-effectiveness of falls prevention 452 interventions for older community-dwelling Australians. Aust N Z J Public Health 2012; 36(3): $453 \quad 241-8$

454 21. Moher D, Liberati A, Tetzlaff J, Altman DG, Group P. Preferred reporting items for 455 systematic reviews and meta-analyses: the PRISMA statement. Int J Surg 2010; 8(5): 336-41.

456 22. Lamb SE, Becker C, Gillespie LD, et al. Reporting of complex interventions in clinical 457 trials: development of a taxonomy to classify and describe fall-prevention interventions. Trials $458 \quad$ 2011; 12: 125.

459 23. de Morton NA. The PEDro scale is a valid measure of the methodological quality of 460 clinical trials: a demographic study. Aust J Physiother 2009; 55(2): 129-33.

461 24. Higgins JP, Thompson SG, Deeks JJ, Altman DG. Measuring inconsistency in meta462 analyses. BMJ 2003; 327(7414): 557-60.

463 25. Higgins JPT, Green S, Cochrane Collaboration. Cochrane handbook for systematic 464 reviews of interventions. Chichester, England ; Hoboken, NJ: Wiley-Blackwell; 2008.

465 26. Harper K BA, Bharat C, Petta A, Deborah G. Edwards GAAC. Risk Assessment and 466 the Impact of Point of Contact Intervention Following Emergency Department Presentation 467 with a Fall. Phys Occup Ther Geriatr 2017; 35(3-4): 182-94.

468 27. Barker A, Cameron P, Flicker L, et al. RESPOND—A patient-centred program to 469 prevent falls in older people presenting to the emergency department with a fall: A randomised 470 contolled trial PLOS Med Under review.

471 28. Vind AB, Andersen HE, Pedersen KD, Jorgensen T, Schwarz P. An outpatient 472 multifactorial falls prevention intervention does not reduce falls in high-risk elderly Danes. $J A m$ 473 Geriatr Soc 2009; 57(6): 971-7.

474 29. Shaw FE, Bond J, Richardson DA, et al. Multifactorial intervention after a fall in older 475 people with cognitive impairment and dementia presenting to the accident and emergency 476 department: Randomised controlled trial. BMJ 2003; 326(7380): 73-5. 
477 30. Chu MM-L, Fong KN-K, Lit AC-H, et al. An Occupational Therapy Fall Reduction 478 Home Visit Program for Community-Dwelling Older Adults in Hong Kong After an Emergency 479 Department Visit for a Fall. J Am Geriatr Soc 2017; 65(2): 364-72.

480 31. Close J, Ellis M, Hooper R, Glucksman E, Jackson S, Swift C. Prevention of falls in the 481 elderly trial (PROFET): a randomised controlled trial. Lancet 1999; 353(9147): 93-7.

482 32. Davison J, Bond J, Dawson P, Steen IN, Kenny RA. Patients with recurrent falls 483 attending Accident \& Emergency benefit from multifactorial intervention - A randomised 484 controlled trial. Age Ageing 2005; 34(2): 162-8.

485 33. Hendriks MR, Bleijlevens MH, van Haastregt JC, et al. Lack of effectiveness of a 486 multidisciplinary fall-prevention program in elderly people at risk: a randomised, controlled trial. 487 J Am Geriatr Soc 2008; 56(8): 1390-7.

488 34. Lightbody E, Watkins C, Leathley M, Sharma A, Lye M. Evaluation of a nurse-led falls 489 prevention programme versus usual care: a randomised controlled trial. Age Ageing 2002; 31(3): $490 \quad 203-10$.

491 35. Matchar DB, Duncan PW, Lien CT, et al. Randomised Controlled Trial of Screening, 492 Risk Modification, and Physical Therapy to Prevent Falls Among the Elderly Recently 493 Discharged From the Emergency Department to the Community: The Steps to Avoid Falls in 494 the Elderly Study. Arch Phys Med Rehabil 2017; 98(6): 1086-96.

495 36. Whitehead C, Wundke R, Crotty M, Finucane P. Evidence-based clinical practice in falls 496 prevention: a randomised controlled trial of a falls prevention service. Aust Health Rev 2003; $497 \quad 26(3): 88-97$.

498 37. Close JCT, Lord SR, Antonova E, et al. Older people presenting to the emergency 499 department after a fall: a population with substantial recurrent healthcare use. Emerg Med J 2012; $500 \quad 29(9): 742$. 
501 38. Lamb SE, Jorstad-Stein EC, Hauer K, Becker C, Prevention of Falls Network E,

502 Outcomes Consensus G. Development of a common outcome data set for fall injury prevention

503 trials: the Prevention of Falls Network Europe consensus. J Am Geriatr Soc 2005; 53(9): 1618-22.

504 39. Schwenk M, Lauenroth A, Stock C, et al. Definitions and methods of measuring and

505 reporting on injurious falls in randomised controlled fall prevention trials: a systematic review.

506 BMC Med Res Methodol 2012; 12(50).

507 40. Nyman SR, Victor CR. Older people's participation in and engagement with falls

508 prevention interventions in community settings: an augment to the Cochrane systematic review.

509 Age Ageing 2012; 41(1): 16-23.

510 41. Haines TP, Day L, Hill KD, Clemson L, Finch C. "Better for others than for me": a

511 belief that should shape our efforts to promote participation in falls prevention strategies. Arch

512 Gerontol Geriatr 2014; 59(1): 136-44.

513

514

515 
Table 1: Characteristics of included studies

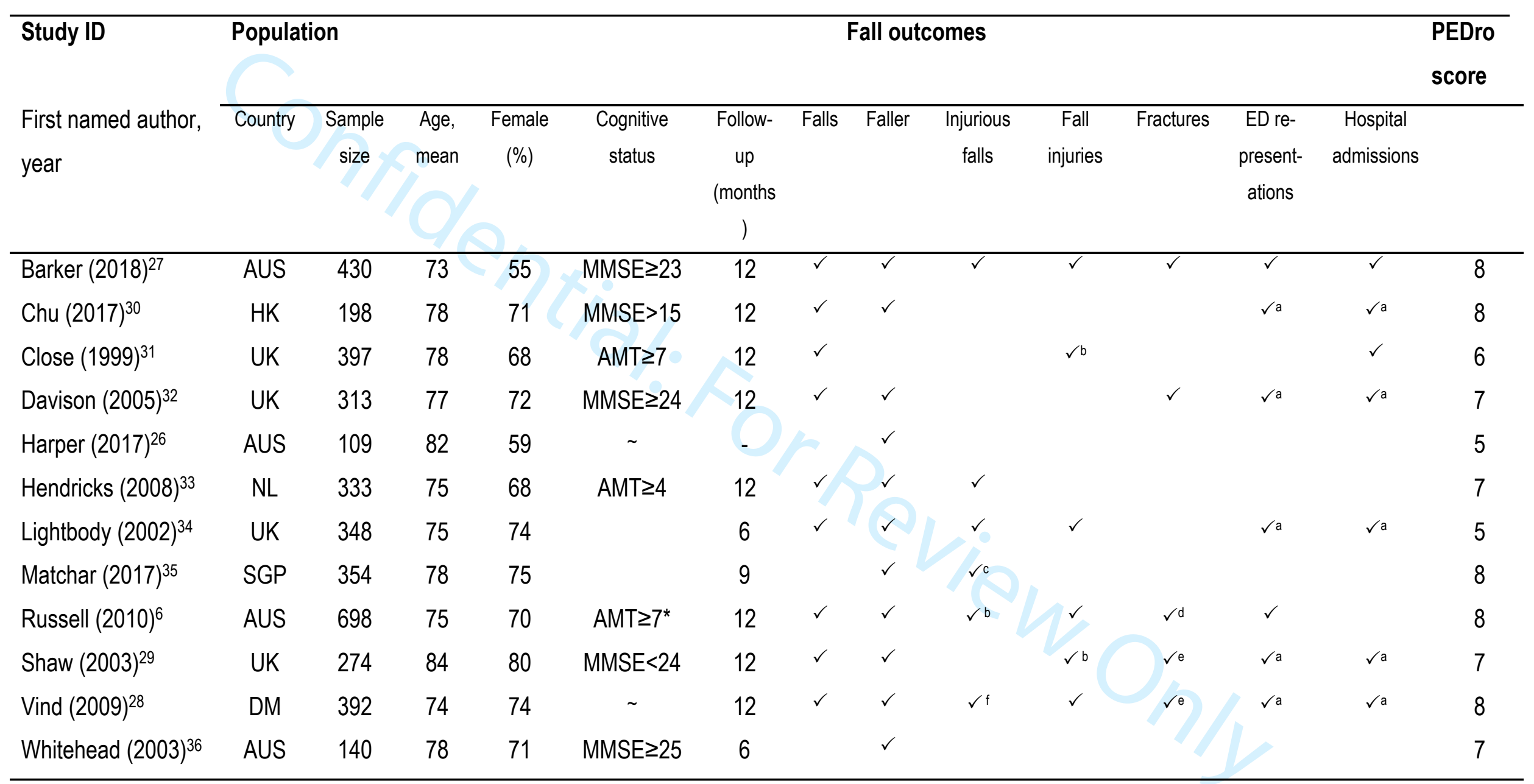

${ }^{*}$ Amended to allow those with AMT $<7$ if carer provided informed consent

$\sim$ No formal assessment tool used, based on medical history or hospital records

- Not reported

HK = Hong Kong; UK = United Kingdom; NL = Netherlands; $A U S$ = Australia; DM = Denmark; SGP = Singapore; $A M T$ = Abbreviated Mental Test; MMSE = Mini-Mental State Examination

aFall related presentations or admissions only 
${ }^{b}$ Major/serious injury only

IInjurious faller

dPeripheral fractures

eFracture neck of femur

FFall caused injury resulting in contact with a healthcare service 
Table 2: Intervention characteristics of included studies

\begin{tabular}{|c|c|c|c|c|c|c|c|c|c|c|c|}
\hline \multirow[t]{2}{*}{ Study ID } & \multicolumn{11}{|c|}{ Intervention characteristics } \\
\hline & 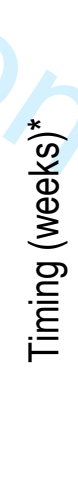 & 今 & 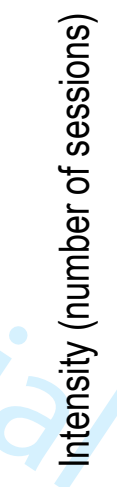 & 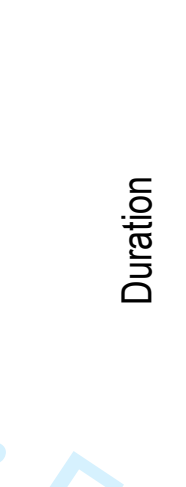 & 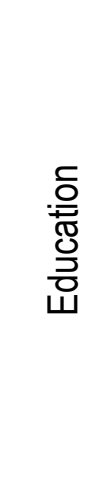 & 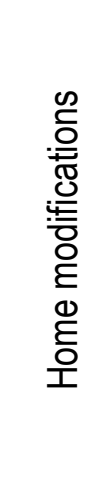 & 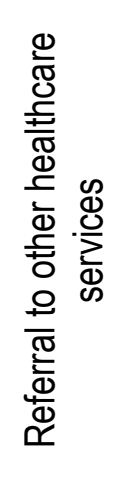 & 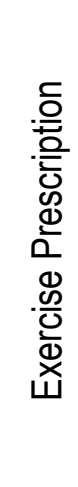 & 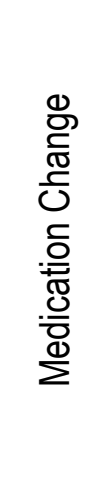 & 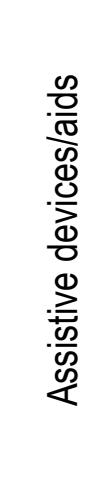 & $\begin{array}{l}\text { 口 } \\
. \frac{C}{E} \\
\stackrel{\mathbb{D}}{\stackrel{D}{J}}\end{array}$ \\
\hline Barker $(2018)^{27}$ & $\leq 2$ & Home, Tele & $3+$ & 6 months & $\checkmark$ & & $\checkmark$ & $\checkmark$ & $\checkmark$ & & $\checkmark$ \\
\hline Chu $(2017)^{30}$ & $\leq 8$ & Home, Tele & $2+$ & 2 months & $\checkmark$ & $\checkmark$ & $\checkmark$ & & & $\checkmark$ & \\
\hline Close $(1999)^{31}$ & - & $\mathrm{DH}$, Home & 2 & - & $\checkmark$ & $\checkmark$ & $\checkmark$ & & $\checkmark$ & $\checkmark$ & \\
\hline Davison $(2005)^{32}$ & - & IP, Home & 2 & - & $\checkmark$ & $\checkmark$ & $\checkmark$ & $\checkmark$ & $\checkmark$ & $\checkmark$ & \\
\hline Harper $(2017)^{26}$ & - & DH, Home, Tele & $3+$ & - & $\checkmark$ & $\checkmark$ & $\checkmark$ & $\checkmark$ & & $\checkmark$ & \\
\hline Hendriks $(2008)^{33}$ & $\leq 4$ & $\mathrm{DH}$, Home & 2 & - & $\checkmark$ & $\checkmark$ & 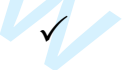 & & & & \\
\hline Lightbody (2002) & $\leq 4$ & Home & 1 & - & $\checkmark$ & $\checkmark$ & $\checkmark$ & & & & \\
\hline Matchar $(2017)^{35}$ & - & Home, Group ${ }^{\dagger}$ & $\leq 24$ & 6 months & $\checkmark$ & $\checkmark$ & $\checkmark$ & & & & \\
\hline Russell $(2010)^{6}$ & $\leq 4$ & Home & 1 & - & $\checkmark$ & & $\checkmark$ & & & & \\
\hline Shaw $(2003)^{29}$ & - & Home & - & 3 months & $\checkmark$ & $\checkmark$ & & $\checkmark$ & $\checkmark$ & $\checkmark$ & \\
\hline Vind $(2009)^{28}$ & 7 & Falls Clinic & $4+$ & - & $\checkmark$ & & $\checkmark$ & $\checkmark$ & $\checkmark$ & & $\checkmark$ \\
\hline
\end{tabular}




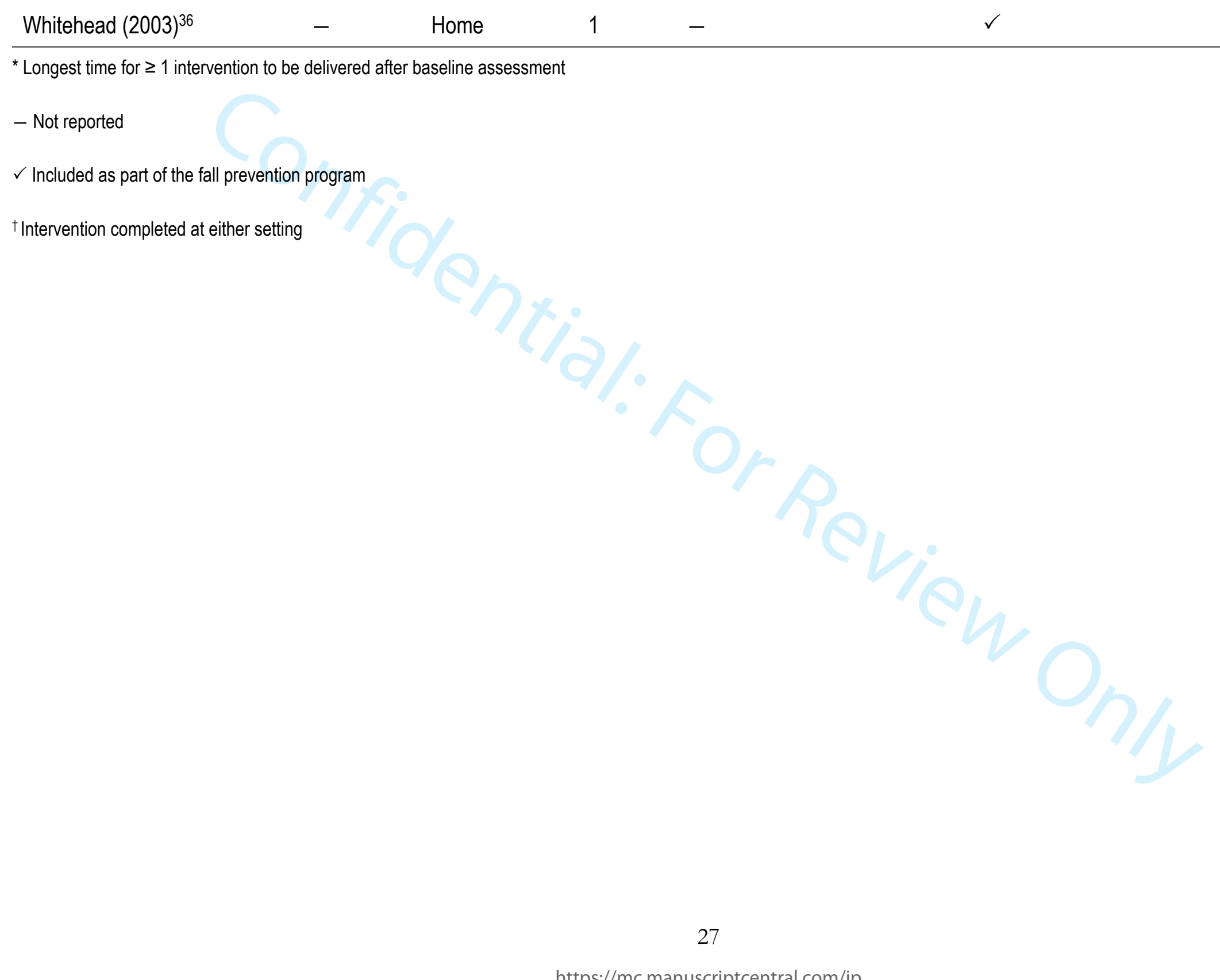




\section{Identification}

\section{Screening}

Eligibility

Included
Studies included in meta-analysis

$$
(\mathrm{n}=12)
$$

Medline $(\mathrm{n}=311)$

Embase $(\mathrm{n}=297)$

CENTRAL $(\mathrm{n}=293)$

CINAHL $(\mathrm{n}=300)$

Articles excluded from title and abstract review $(\mathrm{n}=810)$

Articles excluded after full text review

$$
(\mathrm{n}=29)
$$

Non RCT $(\mathrm{n}=3)$

Not all participants recruited from ED ( $n=15)$

Not a communitybased/multifactorial intervention $(n=5)$

Lacked outcome measure of interest $(n=4)$

Full text not available ( $\mathrm{n}$ $=2$ )

Figure 1: PRISMA flow diagram of study selection process 
(a)

\begin{tabular}{|c|c|c|c|c|c|c|c|}
\hline Study or Subgroup & log[Rate Ratio] & SE & Weight & $\begin{array}{c}\text { Rate Ratio } \\
\text { IV, Random, } 95 \% \mathrm{Cl}\end{array}$ & \multicolumn{3}{|c|}{$\begin{array}{c}\text { Rate Ratio } \\
\text { IV, Random, } 95 \% \mathrm{CI}\end{array}$} \\
\hline Barker 2018 & -0.43 & 0.21 & $10.0 \%$ & $0.65[0.43,0.98]$ & $\rightarrow-1$ & & \\
\hline Chu 2017 & -0.55 & 0.12 & $11.4 \%$ & $0.58[0.46,0.73]$ & $\rightarrow$ & & \\
\hline Close 1999 & -0.89 & 0.09 & $11.8 \%$ & $0.41[0.34,0.49]$ & $=$ & & \\
\hline Davidson 2005 & -0.45 & 0.17 & $10.7 \%$ & $0.64[0.46,0.89]$ & $\rightarrow$ & & \\
\hline Lightbody 2002 & -0.16 & 0.12 & $11.4 \%$ & $0.85[0.67,1.08]$ & & & \\
\hline Russell 2010 & -0.39 & 0.17 & $10.7 \%$ & $0.68[0.49,0.94]$ & & & \\
\hline Shaw 2003 & -0.01 & 0.05 & $12.1 \%$ & $0.99[0.90,1.09]$ & & & \\
\hline Vind 2009 & 0.06 & 0.18 & $10.5 \%$ & $1.06[0.75,1.51]$ & & & \\
\hline Whitehead 2003 & 0.53 & 0.12 & $11.4 \%$ & $1.70[1.34,2.15]$ & & $\rightarrow$ & \\
\hline Total $(95 \% \mathrm{Cl})$ & & & $100.0 \%$ & $0.78[0.58,1.05]$ & & & \\
\hline $\begin{array}{l}\text { Heterogeneity: Tau }{ }^{2} \\
\text { Test for overall effec }\end{array}$ & $\begin{array}{l}19 ; \mathrm{Chi}^{2}=125 . \\
=1.67(\mathrm{P}=0.10\end{array}$ & & & $0001) ;\left.\right|^{2}=94 \%$ & $\begin{array}{lc}0.01 & 0.1 \\
& \text { Favours [expe }\end{array}$ & Favours [co & $\begin{array}{l}10 \\
\text { ontrol] }\end{array}$ \\
\hline
\end{tabular}

(b)

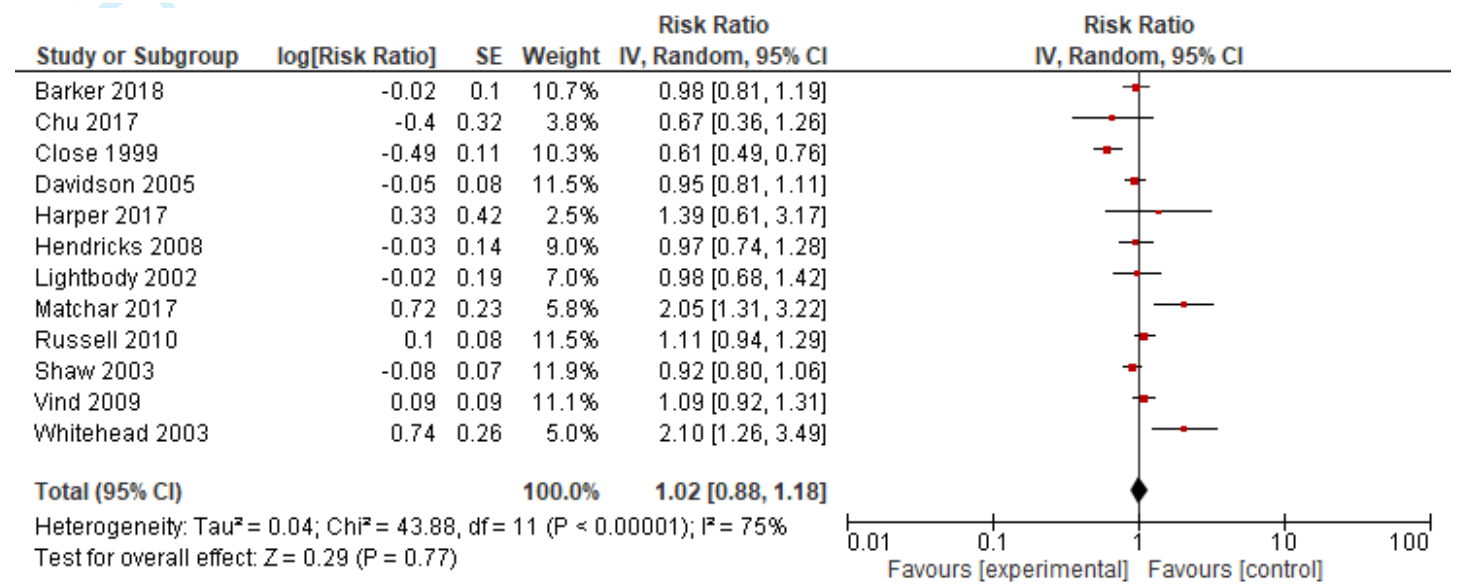
Test for overall effect: $Z=0.29$ ( $P=0.77)$

Risk Ratio

(c)

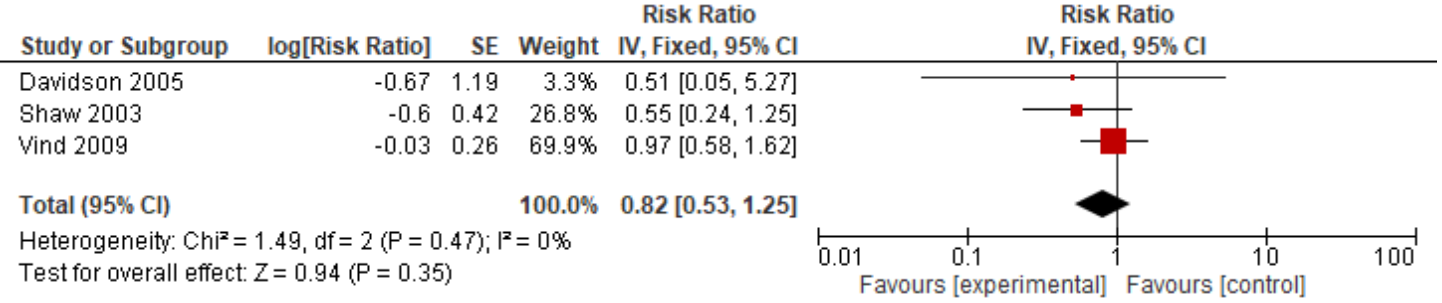

(d)

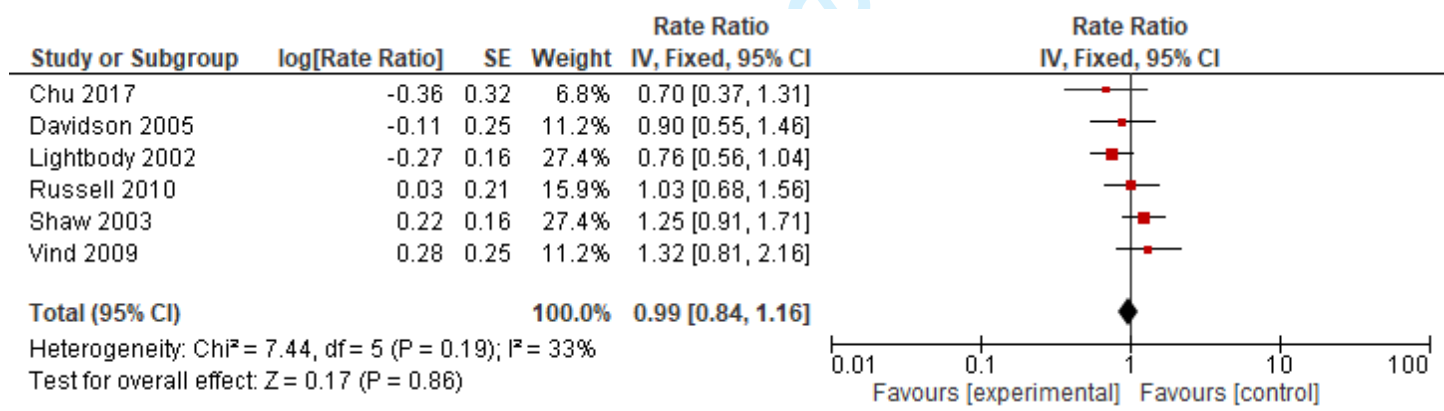

(e)

Rate Ratio

Rate Ratio

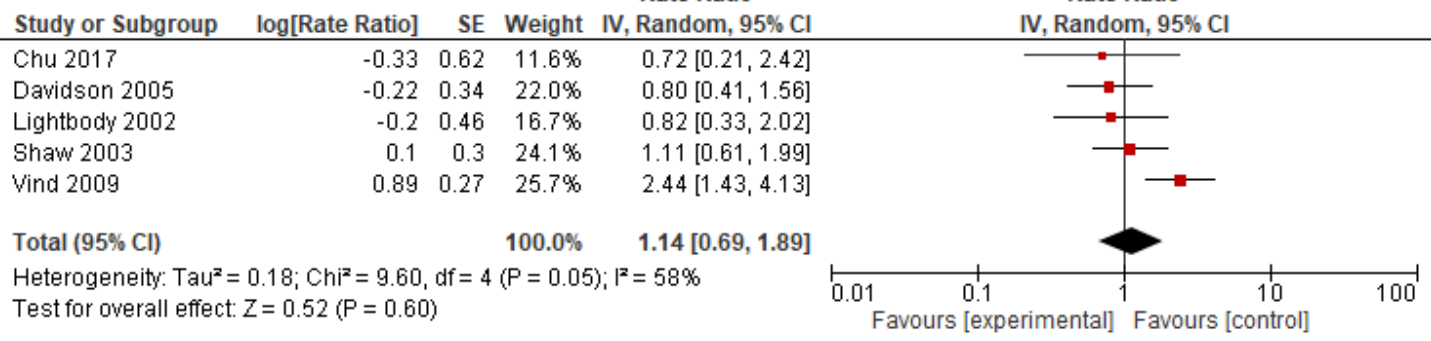

Figure 2: Meta-analysis of effect of multifactorial fall prevention programs on fall outcomes: (a) falls, (b) fallers, (c) neck of femur fractures, (d) fall-related emergency department presentations \& (e) fall-related hospitalisations 


\section{APPENDICES}

Multifactorial falls prevention programs for older adults presenting to the Emergency

Department with a fall: systematic review and meta-analysis

\section{Table of contents}

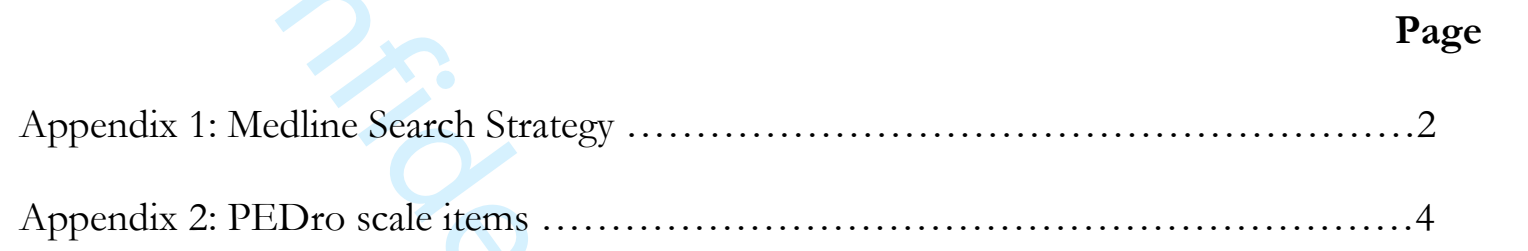

Appendix 3: Risk factor assessment characteristics of included studies . ..............5

Appendix 4: Fall outcomes measured $\ldots \ldots \ldots \ldots \ldots \ldots \ldots \ldots \ldots \ldots \ldots \ldots \ldots \ldots \ldots \ldots \ldots .7$

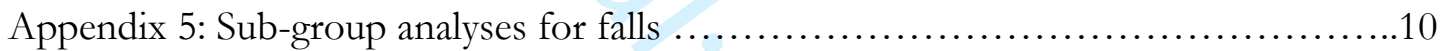




\section{Appendix 1: Medline Search Strategy}

1: Accidental falls/ or fall*.tw.

2: (slip or slips or slipped or slipping).tw.

3: (trip or trips or tripped or tripping).tw

4: 1 or 2 or 3

5: Emergency Medical Services/ or Emergency Medicine/ or exp Emergency Service, Hospital/ or Emergency Treatment/ or Emergency Nursing/ or Emergencies/

6: (emergenc* or emergicient*).tw.

7: exp Hospitalization/ or hospitali*.tw.

8: 5 or 6 or 7

9: $\exp$ Aged/ or Health Services for the Aged/ or Homes for the Aged/ or Housing for the Elderly/ or Nursing Homes/

10: Geriatric Assessment/ or Geriatric Nursing/ or Geriatrics/

11: (elder* or older or aged or geriatric* or gerentol* or senior*).tw.

12: 9 or 10 or 11

13: 4 and 8 and 12

14: (controlled clinical trial or randomized trial).pt.

15: (random* or trial or placebo).tw. or clinical trial*.mp.

16: 14 or 15

$17: 13$ and 16

18: Accidental falls/ or fall*.tw.

19: exp Emergency Service, Hospital/ or Emergencies/ or emergenc*.tw.

20: exp Emergency Medical Services/ or exp Emergency Medicine/ or exp Emergency

Treatment/ or exp Emergency Nursing/

21: exp Hospitalization/ or hospitali*.tw.

22: 19 or 20 or 21

23: exp Aged/ 
24: (elder* or older or aged or geriatric* or gerontol* or senior*).tw.

25: 23 or 24

26: 18 and 22 and 25

27: limit 26 to randomized controlled trial

28: randomi?ed controlled trial*.mp.

29: 26 and 28

30: 27 or 29

31: 17 not 30

32: limit 31 to english 
Appendix 2: PEDro scale items

\begin{tabular}{|c|c|c|c|c|c|c|c|c|c|c|c|c|}
\hline Author, year & $\begin{array}{l}\text { Eligibility } \\
\text { criteria }\end{array}$ & $\begin{array}{l}\text { Random } \\
\text { allocation }\end{array}$ & $\begin{array}{l}\text { Concealed } \\
\text { allocation }\end{array}$ & $\begin{array}{c}\text { Baseline } \\
\text { comparability }\end{array}$ & Subjects & $\begin{array}{l}\text { Blinding } \\
\text { Therapists }\end{array}$ & Assessors & $\begin{array}{l}\text { Adequate } \\
\text { follow-up }\end{array}$ & $\begin{array}{l}\text { Intention- } \\
\text { to-treat } \\
\text { analysis }\end{array}$ & $\begin{array}{c}\text { Between- } \\
\text { group } \\
\text { comparisons }\end{array}$ & $\begin{array}{c}\text { Point } \\
\text { estimates } \\
\text { and } \\
\text { variability }\end{array}$ & $\begin{array}{l}\text { Total } \\
\text { score }\end{array}$ \\
\hline Barker 2018 & $Y$ & $Y$ & $Y$ & $Y$ & $\mathrm{~N}$ & $\mathrm{~N}$ & $Y$ & $Y$ & $Y$ & $Y$ & $Y$ & 8 \\
\hline Chu 2017 & $Y$ & Y & $Y$ & $Y$ & $\mathrm{~N}$ & $\mathrm{~N}$ & $Y$ & $Y$ & $Y$ & $Y$ & $Y$ & 8 \\
\hline Close 1999 & Y & $\mathrm{Y}$ & Y & $Y$ & $\mathrm{~N}$ & $\mathrm{~N}$ & $\mathrm{~N}$ & $\mathrm{~N}$ & $\mathrm{Y}$ & $Y$ & $Y$ & 6 \\
\hline Davison 2005 & Y & Y & $\mathrm{N}$ & $\mathrm{Y}$ & $\mathrm{N}$ & $\mathrm{N}$ & $\mathrm{Y}$ & $Y$ & $\mathrm{Y}$ & Y & $Y$ & 7 \\
\hline Harper 2017 & $Y$ & $Y$ & Y & $\mathrm{N}$ & $\mathrm{N}$ & $\mathrm{N}$ & $Y$ & $Y$ & $\mathrm{~N}$ & $Y$ & $\mathrm{~N}$ & 5 \\
\hline Hendriks 2018 & $Y$ & $Y$ & $Y$ & $Y$ & $\mathrm{~N}$ & $\mathrm{~N}$ & $Y$ & $\mathrm{~N}$ & $Y$ & $Y$ & $Y$ & 7 \\
\hline Lightbody 2002 & Y & Y & $\mathrm{N}$ & Y & $\mathrm{N}$ & $\mathrm{N}$ & $\mathrm{N}$ & $Y$ & $\mathrm{~N}$ & Y & $Y$ & 5 \\
\hline Matchar 2017 & $Y$ & Y & Y & $Y$ & $\mathrm{~N}$ & $\mathrm{~N}$ & $Y$ & $Y$ & $Y$ & $Y$ & Y & 8 \\
\hline Russell 2010 & $Y$ & $Y$ & Y & Y & $\mathrm{N}$ & $\mathrm{N}$ & $Y$ & $Y$ & $Y$ & Y & Y & 8 \\
\hline Shaw 2003 & $Y$ & $Y$ & Y & Y & $\mathrm{N}$ & $\mathrm{N}$ & $\mathrm{N}$ & Y & Y & Y & Y & 7 \\
\hline Vind 2009 & $Y$ & $Y$ & Y & Y & $\mathrm{N}$ & $\mathrm{N}$ & $Y$ & $Y$ & $Y$ & $Y$ & Y & 8 \\
\hline Whitehead 2003 & Y & $Y$ & Y & Y & $\mathrm{N}$ & $\mathrm{N}$ & $Y$ & $\mathrm{~N}$ & $\mathrm{~N}$ & $Y$ & Y & 7 \\
\hline
\end{tabular}


Appendix 3: Risk factor assessment characteristics of included studies

Risk factor assessment

\begin{tabular}{|c|c|c|c|c|c|c|c|c|c|c|c|c|c|c|c|}
\hline Study ID & 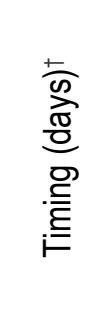 & क & 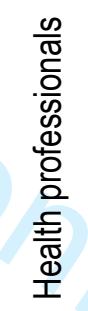 & 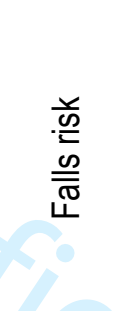 & 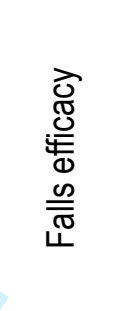 & 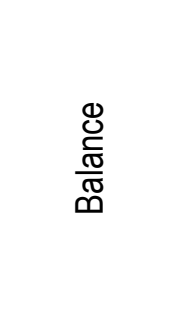 & 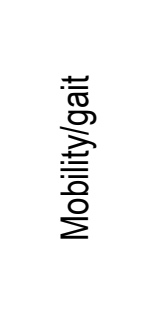 & 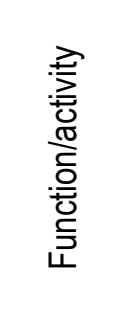 & 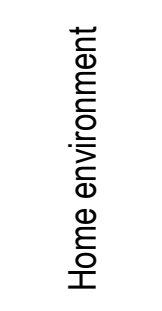 & 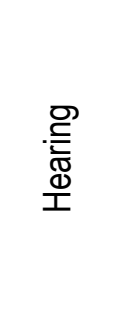 & 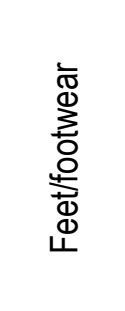 & $\stackrel{\text { 응 }}{\stackrel{5}{>}}$ & $\begin{array}{l}\frac{\bar{\sigma}}{\bar{\sigma}} \\
\frac{0}{\bar{D}} \\
\stackrel{0}{>}\end{array}$ & 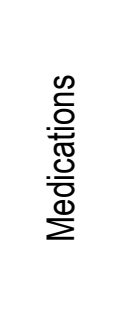 & 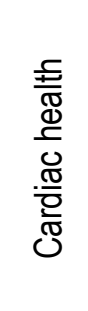 \\
\hline $\begin{array}{l}\text { Barker } \\
(2018)^{27}\end{array}$ & $\leq 14$ & Home & $\begin{array}{l}\text { OT } \\
\text { PT } \\
\text { RN } \ddagger\end{array}$ & $\begin{array}{c}\text { FROP- } \\
\text { Com }\end{array}$ & $\begin{array}{l}\text { Short } \\
\text { FES-I }\end{array}$ & $\begin{array}{l}\text { FROP- } \\
\text { Com }\end{array}$ & $\begin{array}{c}\text { FROP- } \\
\text { Com }\end{array}$ & & $\begin{array}{c}\text { FROP- } \\
\text { Com }\end{array}$ & & $\begin{array}{c}\text { FROP- } \\
\text { Com }\end{array}$ & $\begin{array}{c}\text { FROP- } \\
\text { Com }\end{array}$ & & $\begin{array}{l}\text { FROP- } \\
\text { Com }\end{array}$ & \\
\hline Chu $(2017)^{30}$ & $\leq 14$ & Home & OT & & 4 & 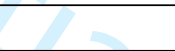 & & & WHSA & & & & & & \\
\hline Close $(1999)^{31}$ & - & $\begin{array}{c}\mathrm{DH} \\
\text { Home }\end{array}$ & $\begin{array}{l}\text { MD } \\
\text { OT }\end{array}$ & & $\mathrm{FHI}$ & 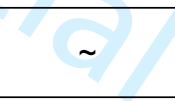 & & $\mathrm{MBI}$ & Checklist & & & Snellen & & $\sim$ & $\mathrm{OH}$ \\
\hline $\begin{array}{l}\text { Davison } \\
(2005)^{32}\end{array}$ & - & $\begin{array}{c}\text { IP } \\
\text { Home }\end{array}$ & $\begin{array}{l}\text { MD } \\
\text { PT } \\
\text { OT }\end{array}$ & & & 0 & POMS & & USER & & POMS & Snellen & & $\sim$ & $\mathrm{OH}$ \\
\hline $\begin{array}{l}\text { Harper } \\
(2017)^{26}\end{array}$ & - & ED & $\begin{array}{c}\mathrm{OT} \\
\mathrm{PT}^{\ddagger}\end{array}$ & $\begin{array}{c}\text { FROP- } \\
\text { Coms }\end{array}$ & & $\begin{array}{c}\text { FROP- } \\
\text { Com }\end{array}$ & $\begin{array}{l}\text { FROP- } \\
\text { Com }\end{array}$ & 8 & $\begin{array}{c}\text { FROP- } \\
\text { Com }\end{array}$ & & $\begin{array}{c}\text { FROP- } \\
\text { Com }\end{array}$ & $\begin{array}{c}\text { FROP- } \\
\text { Com }\end{array}$ & & $\begin{array}{c}\text { FROP- } \\
\text { Com }\end{array}$ & \\
\hline $\begin{array}{l}\text { Hendricks } \\
(2008)^{33}\end{array}$ & $\leq 30$ & $\begin{array}{c}\mathrm{DH} \\
\text { Home }\end{array}$ & $\begin{array}{l}\mathrm{MD} \\
\mathrm{OT}\end{array}$ & & $\mathrm{FHI}$ & Rhomberg & GnG & $\begin{array}{c}\text { FAl } \\
\text { GARS }\end{array}$ & $\mathrm{CDC}$ & Whisp & $\sim$ & Snellen & & $\sim$ & $\mathrm{OH}$ \\
\hline $\begin{array}{l}\text { Lightbody } \\
(2002)^{34}\end{array}$ & $14-28$ & Home & $\mathrm{RN}$ & & & Rhomberg & S-test & & $\sim$ & $\sim$ & $\sim$ & Snellen & $\sim$ & $\sim$ & $\begin{array}{c}\mathrm{ECG} \\
\mathrm{OH}\end{array}$ \\
\hline $\begin{array}{l}\text { Matchar } \\
(2017)^{35}\end{array}$ & - & $\begin{array}{c}\mathrm{DH} \\
\text { Home }\end{array}$ & $\begin{array}{l}\mathrm{PT} \\
\mathrm{MD} \\
\end{array}$ & & & & SPPB & & CDC & & & Snellen & & $\sim$ & $\sim$ \\
\hline $\begin{array}{l}\text { Russell } \\
(2010)^{6}\end{array}$ & $\leq 30$ & Home & $\begin{array}{l}\mathrm{MD} \\
\mathrm{OT} \\
\mathrm{PT} \\
\mathrm{RF}^{\ddagger}\end{array}$ & $\begin{array}{c}\text { FROP- } \\
\text { Com }\end{array}$ & MFES & $\begin{array}{c}\text { FROP. } \\
\text { Com }\end{array}$ & $\begin{array}{l}\text { FROP- } \\
\text { Com }\end{array}$ & & $\begin{array}{c}\text { FROP. } \\
\text { Com }\end{array}$ & & $\begin{array}{c}\text { FROP- } \\
\text { Com }\end{array}$ & $\begin{array}{c}\text { FROP- } \\
\text { Com }\end{array}$ & & $\begin{array}{c}\text { FROP- } \\
\text { Com }\end{array}$ & $\sim$ \\
\hline Shaw $(2003)^{29}$ & - & Home & $\begin{array}{l}\text { MD } \\
\text { OT } \\
\text { PT }\end{array}$ & & & & mPOMA & & Checklist $^{\times}$ & & $\sim$ & $\begin{array}{c}\text { Snellen } \\
\text { VAA }\end{array}$ & & $\sim$ & $\mathrm{OH}$ \\
\hline
\end{tabular}




\begin{tabular}{|c|c|c|c|c|c|c|c|c|c|c|}
\hline Vind $(2009)^{28}$ & - & $\begin{array}{l}\text { Falls } \\
\text { Clinic }\end{array}$ & $\begin{array}{l}\mathrm{MD} \\
\mathrm{RN} \\
\mathrm{PT}\end{array}$ & PPA & BBS & $\begin{array}{l}\text { DGI } \\
\text { TUG }\end{array}$ & 30STS & VAA & $\sim$ & $\begin{array}{c}\mathrm{ECG} \\
\mathrm{OH}\end{array}$ \\
\hline
\end{tabular}

\section{$(2003)^{36}$}

- Not reported

$\sim$ Included in assessment but no formal assessment tool used

$\dagger$ Time for assessment to delivered after fall/discharge from ED

$\ddagger$ Assessment completed by one healthcare professional from one of the list professions

$\checkmark$ Two item screening tool was also used to assess falls risk

$\mathrm{MD}=$ Doctor; $\mathrm{OT}=$ Occupational Therapist; $\mathrm{PT}=$ Physiotherapist; $\mathrm{MD}=$ Medical doctor; RN = Registered Nurse; $\mathrm{D}=$ Dietitian; RF = Research Fellow

Home = Home visit or home based intervention; Tele = Telephone follow up calls; DH = Day Hospital; IP = Inpatient hospital; Group = Group program in out patient setting

FROP-Com = Falls Risk for Older People in the Community; Short FES-I = Falls Efficacy Scale-International (Short version); WHSA = Westmead Home Safety Assessment; Snellen = Snellen chart; $\mathrm{FHI}=$ Falls handicap inventory; Checklist $=$ Environment hazards checklist designed by the Health and Safety Executive, UK; $\mathrm{OH}=$ orthostatic/postural hypotension; $\mathrm{POMS}=$

Performance Orientated Mobility Score; USER = User Safety and Environmental Risk checklist for home environment hazards; Romberg = The Romberg test of proprioception; FAI = Frenchay Activities Index; GnG = Get up and Go; GARS = Groningen Activity Restriction Scale; CDC = Centers for Disease Control and Prevention Home Checklist; Checklist ${ }^{\star}=$ Assessment of Environmental fall hazards using a standard checklist; Whisp = Whisper voice test; S-test = The 'S' test for selecting mobility aids within an institutional setting; ECG = Electrocardiography; MFES = Modified version of the Falls Efficacy Scale; SPPB = Short Physical Performance Battery; mPOMA = modified version of the Performance Orientated Mobility Assessment; Checklist ${ }^{\star}=$ Assessment of environmental fall hazards using a standard checklist; VAA = Visual acuity assessment; PPA = A physiological profile approach to fall risk assessment (short version); BBS = Berg Balance Scale; DGI = Dynamic Gait Index; TUG = Timed up and go; 30STS = Sit to stand in 30 seconds 
Appendix 4: Fall outcomes measured

\begin{tabular}{|c|c|c|c|}
\hline Reference & Outcome measure collected & Definition of fall outcomes & Data collection mode \\
\hline Barker 2018 & $\begin{array}{l}\text { Primary outcomes were falls and fall injuries per } \\
\text { person-year over the 12-month study period. Falls } \\
\text { may result in multiple injuries. As such, data on } \\
\text { injurious falls (falls with at least one injury) were } \\
\text { also recorded. } \\
\text { Secondary outcomes included ED re- } \\
\text { presentations, hospitalisations, fractures } \\
\text { (confirmed by radiological investigation) and } \\
\text { deaths per person-year over the 12-month study } \\
\text { period. }\end{array}$ & $\begin{array}{l}\text { Fall: an event resulting in a person coming to rest } \\
\text { inadvertently on the ground, floor or other lower } \\
\text { level. } \\
\text { Fall injury: any physical harm resulting from a fall } \\
\text { (including fractures, dislocations, sprain, skin tears } \\
\text { and bruising), reported by study participants. }\end{array}$ & $\begin{array}{l}\text { Fall outcomes: Self-reported via monthly } \\
\text { fall calendars and blinded assessor } \\
\text { telephone calls } \\
\text { Hospital utilisation: Self-reported via } \\
\text { monthly fall calendars and blinded assessor } \\
\text { telephone calls and verified using hospital } \\
\text { administrative datasets }\end{array}$ \\
\hline Chu 2017 & $\begin{array}{l}\text { Primary outcomes included number of fallers and } \\
\text { repeated fallers, number of falls and recurrent falls, } \\
\text { time until first fall, number of ED visits because of } \\
\text { falls, and length of hospital stays primarily due to } \\
\text { falls in the 12-month follow-up period. } \\
\text { Secondary outcomes included measurements } \\
\text { during follow-up calls-telephone Barthel Index-50 } \\
\text { (MBI), the Chinese version of the Frenchay } \\
\text { Activities Index (FAl), and the Chinese version of } \\
\text { the 4-item Geriatric Depression Scale (GDS). }\end{array}$ & $\begin{array}{l}\text { Fall: an event that results in a person coming to } \\
\text { rest inadvertently on the ground or hitting an object } \\
\text { like a chair or stair. Individuals who fell because of } \\
\text { excess alcohol intake or sustained a sudden blow } \\
\text { or loss of consciousness or sudden onset of } \\
\text { paralysis due to stroke or an epileptic seizure were } \\
\text { excluded. }\end{array}$ & $\begin{array}{l}\text { Fall outcomes: Self-reported via blinded } \\
\text { assessor telephone calls to ask about } \\
\text { subsequent falls }\end{array}$ \\
\hline Close 1999 & $\begin{array}{l}\text { Primary endpoint was subsequent falls } \\
\text { Secondary outcomes were death, major injury, } \\
\text { moves to institutional care, functional status, and } \\
\text { use of health care. }\end{array}$ & $\begin{array}{l}\text { Fall: inadvertently coming to rest on the ground or } \\
\text { other lower level with or without loss of } \\
\text { consciousness and other than as a consequence } \\
\text { of sudden onset of paralysis, epileptic seizure, } \\
\text { excess alcohol intake, or overwhelming external } \\
\text { force. } \\
\text { Fall injury: the number of serious injuries (fracture } \\
\text { or joint dislocation) }\end{array}$ & $\begin{array}{l}\text { Fall and healthcare utilisation outcomes: } \\
\text { Self-reported via monthly calendars }\end{array}$ \\
\hline
\end{tabular}




\begin{tabular}{|c|c|c|c|}
\hline Davidson 2005 & $\begin{array}{l}\text { Primary outcome was the number of falls and the } \\
\text { number of subjects who fell again during } 1 \text { year of } \\
\text { follow-up. } \\
\text { Secondary outcome measures were injury rates } \\
\text { and fall-related hospitalisation, mortality, and } \\
\text { changes in fall efficacy (Activities specific Balance } \\
\text { Confidence Scale). }\end{array}$ & $\begin{array}{l}\text { Fall: inadvertently coming to rest on the ground or } \\
\text { other lower level with or without loss of } \\
\text { consciousness or injury. } \\
\text { Fall injury: not defined }\end{array}$ & $\begin{array}{l}\text { Fall outcomes: Self-reported via monthly } \\
\text { fall calendars and blinded assessor } \\
\text { telephone calls } \\
\text { Hospital utilisation: Self-reported via } \\
\text { monthly calendars and blinded assessor } \\
\text { telephone calls and verified with hospital } \\
\text { records }\end{array}$ \\
\hline Harper 2017 & $\begin{array}{l}\text { Primary outcome measure was the fall frequency } \\
\text { among patients between ED discharge and } \\
\text { commencement with the falls specific service. } \\
\text { Secondary outcomes were time from discharge to } \\
\text { next fall, attendance rates at the falls specific } \\
\text { service, reason for nonattendance and death. }\end{array}$ & $\begin{array}{l}\text { Fall: any presentation where patients had come to } \\
\text { rest on the ground, floor, or lower level. }\end{array}$ & $\begin{array}{l}\text { Fall outcomes: Self-reported via monthly } \\
\text { fall calendars and blinded assessor } \\
\text { telephone calls }\end{array}$ \\
\hline Hendriks 2008 & $\begin{array}{l}\text { Primary outcome measures were falls (falls, } \\
\text { recurrent falls, "injurious falls", and time to first fall) } \\
\text { and daily functioning. }\end{array}$ & $\begin{array}{l}\text { Fall: an event that results in a person coming to } \\
\text { rest inadvertently on the ground or other lower } \\
\text { level. } \\
\text { Injurious fall: the percentage of participants who } \\
\text { sought medical care after a fall. }\end{array}$ & $\begin{array}{l}\text { Fall outcomes: Self-reported via monthly } \\
\text { fall calendars and blinded assessor } \\
\text { telephone calls }\end{array}$ \\
\hline Lightbody 2002 & $\begin{array}{l}\text { Primary outcome was further falls, consequent } \\
\text { injury and subsequent place of treatment were } \\
\text { recorded. } \\
\text { Secondary outcome were functional ability, re- } \\
\text { attendance at the Accident and Emergency } \\
\text { Department and admission to hospital. }\end{array}$ & $\begin{array}{l}\text { Fall: patient failing to maintain a stable position } \\
\text { and inadvertently coming to rest on the ground or } \\
\text { lower level, with or without loss of consciousness, } \\
\text { but not as the result of acute medical events or } \\
\text { extraordinary environmental factors. Coming to rest } \\
\text { against furniture or a wall was not deemed a fall. } \\
\text { Fall injury: not defined }\end{array}$ & $\begin{array}{l}\text { Fall outcomes: Self-reported via monthly } \\
\text { fall calendars and blinded assessor } \\
\text { telephone calls } \\
\text { Hospital utilisation: Self-reported via } \\
\text { monthly calendars and triangulated with } \\
\text { hospital and GP records }\end{array}$ \\
\hline Matcher 2017 & $\begin{array}{l}\text { Primary outcome measure was experiencing at } \\
\text { least } 1 \text { fall during the 9-month study period. } \\
\text { Secondary outcome measures were the } \\
\text { occurrence of at least } 1 \text { injurious fall during the } \\
\text { study period and a change in the Short Physical } \\
\text { Performance Battery (SPPB) score. }\end{array}$ & $\begin{array}{l}\text { Fall: an event which results in a person coming to } \\
\text { rest inadvertently on the ground or floor or other } \\
\text { lower level } \\
\text { Injurious fall: a fall for which the participant } \\
\text { sought medical attention or restricted his/her daily } \\
\text { activities for at least } 48 \text { hours. }\end{array}$ & $\begin{array}{l}\text { Fall outcomes: Self-reported via monthly } \\
\text { fall calendars }\end{array}$ \\
\hline
\end{tabular}




\begin{tabular}{|c|c|c|c|}
\hline Russell 2010 & $\begin{array}{l}\text { Primary outcome measures were falls and injuries } \\
\text { as a result of these falls, over the } 12 \text {-month follow- } \\
\text { up period. } \\
\text { Secondary outcome measures of serious injury } \\
\text { (Abbreviated Injury Score }>2 \text { ) and peripheral } \\
\text { fractures were summarised and compared using } \\
\text { the same methods used for the primary outcomes. }\end{array}$ & $\begin{array}{l}\text { Fall: based on the Kellogg International Working } \\
\text { Group definition: "an event which results in a } \\
\text { person coming to rest inadvertently on the ground } \\
\text { or some lower level, and other than as a } \\
\text { consequence of sustaining a violent blow, loss of } \\
\text { consciousness, sudden onset of paralysis as in } \\
\text { stroke or an epileptic seizure." } \\
\text { Injurious fall: number of participants sustaining a } \\
\text { fall or injury } \\
\text { Serious fall injury: Injuries sustained as a result } \\
\text { of falling were assessed for severity using the } \\
\text { Abbreviated Injury Score. Serious fall injuries = } \\
\text { Abbreviated Injury Score >2 }\end{array}$ & $\begin{array}{l}\text { Fall outcomes: Self-reported via monthly } \\
\text { fall calendars and blinded assessor } \\
\text { telephone calls } \\
\text { Hospital utilisation: Self-reported via } \\
\text { monthly calendars and blinded assessor } \\
\text { telephone calls and verified with hospital } \\
\text { records }\end{array}$ \\
\hline Shaw 2003 & $\begin{array}{l}\text { Primary outcome measure was number of } \\
\text { participants who fell at least once in the year after } \\
\text { intervention. } \\
\text { Secondary outcome measures were number of } \\
\text { falls (corrected for diary returns), time to first fall, } \\
\text { injury rates, fall related attendance at accident and } \\
\text { emergency department, fall related hospital } \\
\text { admissions, and mortality. }\end{array}$ & $\begin{array}{l}\text { Fall: an event reported by either the person who } \\
\text { fell or a witness, resulting in the patient } \\
\text { inadvertently coming to rest on the ground or at } \\
\text { another lower level with or without loss of } \\
\text { consciousness or injury } \\
\text { Fall injury: major injury or fractured neck of femur }\end{array}$ & $\begin{array}{l}\text { Fall outcomes: Self-reported via weekly fall } \\
\text { calendars and blinded assessor telephone } \\
\text { calls } \\
\text { Hospital utilisation: Hospital } \\
\text { computerized records }\end{array}$ \\
\hline Vind 2009 & $\begin{array}{l}\text { Primary outcome of the study was total number of } \\
\text { falls. Secondary outcome measures were number } \\
\text { of injurious falls, fallers, frequent fallers ( }>3 \text { falls } \\
\text { per year), time to first fall and first injury. }\end{array}$ & $\begin{array}{l}\text { Fall: unintentionally coming to rest on the floor, } \\
\text { ground, or other lower level. } \\
\text { Injurious fall: fall caused injury resulting in contact } \\
\text { with a general practitioner, emergency department } \\
\text { or admission to the hospital. }\end{array}$ & $\begin{array}{l}\text { Fall outcomes: Self-reported via weekly fall } \\
\text { calendars and blinded assessor telephone } \\
\text { calls } \\
\text { Hospital utilisation: Hospital } \\
\text { computerized records }\end{array}$ \\
\hline $\begin{array}{l}\text { Whitehead } \\
2003\end{array}$ & $\begin{array}{l}\text { Principal outcome measure was the uptake of } \\
\text { recommended evidence-based strategy at six } \\
\text { months. } \\
\text { Self-reported fall rate over the ensuing six month } \\
\text { period was also assessed. }\end{array}$ & $\begin{array}{l}\text { Fall: inadvertently coming to rest on the ground or } \\
\text { other lower level with or without loss of } \\
\text { consciousness and other than as a consequence } \\
\text { of a major intrinsic or extrinsic event. }\end{array}$ & $\begin{array}{l}\text { Fall outcomes: Self-reported via weekly fall } \\
\text { calendars and blinded assessor telephone } \\
\text { calls }\end{array}$ \\
\hline
\end{tabular}




\section{Appendix 5: Sub-group analyses for falls}

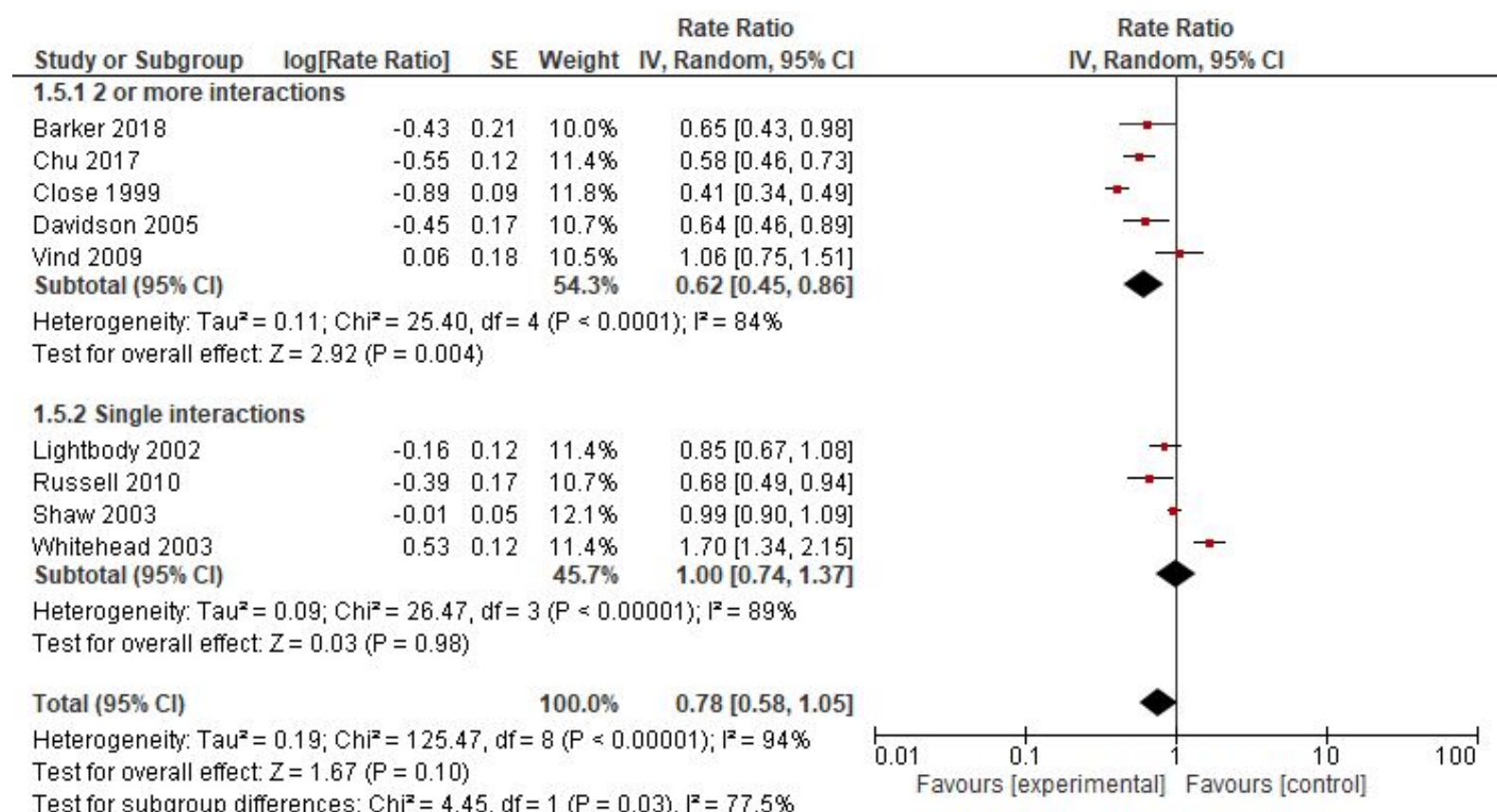

\section{a) Meta-analysis by intensity of treatments}

Rate Ratio

Rate Ratio

\begin{tabular}{|c|c|c|c|c|}
\hline Study or Subgroup & log[Rate Ratio] & SE & Weight & IV, Random, $95 \% \mathrm{C}$ \\
\hline \multicolumn{5}{|l|}{ 1.7.1 Referrals only } \\
\hline $\begin{array}{l}\text { Whitehead } 2003 \\
\text { Subtotal }(95 \% \mathrm{Cl})\end{array}$ & 0.53 & 0.12 & $\begin{array}{l}11.4 \% \\
11.4 \%\end{array}$ & $\begin{array}{l}1.70[1.34,2.1 \\
1.70[1.34,2.1\end{array}$ \\
\hline \multicolumn{5}{|c|}{$\begin{array}{l}\text { Heterogeneity: Not applicable } \\
\text { Test for overall effect: } Z=4.42(P \leq 0.0001)\end{array}$} \\
\hline \multicolumn{5}{|c|}{ 1.7.2 Other interventions } \\
\hline Barker 2018 & -0.43 & 0.21 & $10.0 \%$ & $0.65[0.43,0.9$ \\
\hline Chu 2017 & -0.55 & 0.12 & $11.4 \%$ & $0.58[0.46,0.7$ \\
\hline Close 1999 & -0.89 & 0.09 & $11.8 \%$ & $0.41[0.34,0.4$ \\
\hline Davidson 2005 & -0.45 & 0.17 & $10.7 \%$ & $0.64[0.46,0.8$ \\
\hline Lightbody 2002 & -0.16 & 0.12 & $11.4 \%$ & $0.85[0.67,1.0$ \\
\hline Russell 2010 & -0.39 & 0.17 & $10.7 \%$ & $0.68[0.49,0$ \\
\hline Shaw 2003 & -0.01 & 0.05 & $12.1 \%$ & $0.99[0.90,1.0$ \\
\hline $\begin{array}{l}\text { Vind } 2009 \\
\text { Subtotal }(95 \% \mathrm{Cl})\end{array}$ & 0.06 & 0.18 & $\begin{array}{l}10.5 \% \\
88.6 \%\end{array}$ & $\begin{array}{l}1.06[0.75,1 . \\
0.70[0.53,0 .\end{array}$ \\
\hline
\end{tabular}

Heterogeneity: $\mathrm{Tau}^{2}=0.15 ; \mathrm{Chi}^{2}=86.16, \mathrm{df}=7(\mathrm{P}<0.00001) ; \mathrm{I}^{2}=92 \%$

Test for overall effect: $Z=2.46(P=0.01)$

Total $(95 \% \mathrm{Cl})$

$100.0 \% \quad 0.78[0.58,1.05]$

Heterogeneity: $\mathrm{Tau}^{2}=0.19 ; \mathrm{Chi}^{2}=125.47, \mathrm{df}=8(\mathrm{P}<0.00001) ; \mathrm{I}^{2}=94 \%$

Test for overall effect: $Z=1.67(P=0.10)$

Test for subqroup differences: $\mathrm{Chi}^{\mathrm{z}}=22.24, \mathrm{df}=1(\mathrm{P} \leq 0.00001), \mathrm{I}^{\mathrm{z}}=95.5 \%$

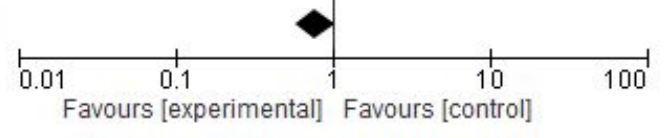

b) Meta-analysis by type of treatments i.e. referrals vs other 